\title{
Geology unpacked
}

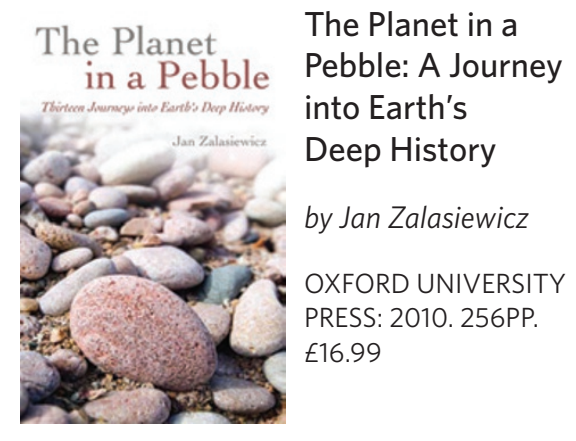

$\mathrm{T}$ his readable book is a celebratory rumination on geology, in the widest sense. It begins with the origin of elements and ends with the demise of the Solar System. In between is everything else, from core formation and mantle convection to ancient oceanography, mountain building, weathering and erosion. The pebble in the title - a distant echo of the sand grain in William Blake's Auguries of Innocence - is a rounded slate from a beach in west Wales, and the book is divided into 13 chapters, each exploring a different stage in the history of the material from which the pebble is made. The choice of slate as the repository for these true tales is an inspired one, allowing Zalasiewicz to construct a chronicle that includes all the principal facets of the rock cycle. In short, this is a first year undergraduate course on planet Earth told as a fireside narrative.

I found the book to be most successful in the parts that combined the stuff of Zalasiewicz's home scientific territory of the early Palaeozoic history of Wales with other aspects of geology that were, to me, less familiar. One of the most interesting topics in this respect was an exploration of what life in a graptolite colony must have entailed. Graptolites are the generally unspectacular fossils that look a bit like pencil lines in the rock, and that students like to try to fake to catch out their wary tutors. Geologists tend to think of graptolites as dead fossils rather than living organisms, but Zalasiewicz asks the reader to consider these prehistoric curiosities in relation to today's marine ecosystems. Some surprising possibilities arise, including a role for these creatures in ancient ocean mixing. This trick of presenting the reader with surprising conjectures is one that Zalasiewicz applies to a suite of topics including, home territory for him again, the geological future of the planet (and the pebble). In effect, he is giving free reign to the urge that many scientists have to let the imagination off the leash without having to go into detail about the supporting data and arguments.

As one might expect from an author who has written, provokingly, about the meaning of time in formal stratigraphy, the importance of chronology is well illustrated. The academic debate, one might even call it a mini controversy, has revolved around the merits of applying spatial terms - such as 'lower' and 'upper' to rocks. These longstanding geological terms were derived from observations of horizontally layered strata. But it has been argued that we would all be much better off sticking to strictly time-related terms such as 'early' and 'late.' An element in the argument, articulated particularly effectively by Zalasiewicz, is that any rock will contain physical and chemical evidence of a multitude of events and phases, all occurring at different dates that have very little to do with sediment being laid down in horizontal beds.

\section{The choice of slate as a repository for these true tales is an inspired one, allowing Zalasiewicz to construct a chronicle that includes all the principal facets of the rock cycle.}

Zalasiewicz reveals the remarkable number of methods, old and new, that can be used to date events in the life of a slate pebble across the entire span of Earth history. The formation of ancient continents from which the sediment that made the slate was derived, the deposition of this sediment in the ancient ocean and the migration of hydrocarbons formed from buried organic matter are just some of the events that can be dated using the mostly isotopic methods that Zalasiewicz marvels at. In this way, the numerous possible ages of the pebble are nicely uncovered, each encoded in a different part of its fabric.

In a small way, human history runs alongside planetary history. Some of the geological discoveries are illustrated through vignettes from the lives of the scientists behind them. Charles Lapworth, for example, left his native southern England to live the life of a romantic in the Scottish landscape popularized at the time by Sir Walter Scott. It was here that Lapworth discovered graptolites, which became for him the lifelong obsession that led eventually to new insights about the true structure of the Scottish upland crust - he showed how it had been telescoped in a mountain-building process. This interpretation brought Lapworth into conflict with the stratigraphic luminaries of the day. The human narratives keep the geological stories bubbling along and give the book its readable pace.

However, the book is not without some details that niggle. There are a few graphic and typographic infelicities, a numerical error early on in the book concerning the Avogadro constant being one of the most perturbing. Irritatingly, the captions for the good quality images are placed at the beginning of the book, whereas the images themselves are gathered towards the middle. Schematics would have helped to convey some of the more complex ideas where words alone are inadequate. It is a shame, too, that the pebble on the dust jacket looks distinctly closer to sandstone than slate. But these are small grievances.

A book about the history of the planet that has content to satisfy the interested amateur and the professional alike is a tall order. This one has the ingredients and just about meets the challenge. There have been similar books before, most sweepingly and successfully Bill Bryson's A Short History of Nearly Everything, but Zalasiewicz, as a careful professional, has here written an elegant volume that unpretentiously unwraps the vast scope of geology as exemplified by the most commonplace of objects, and it is a job that is well and thoughtfully done.

\section{REVIEWED BY STEPHEN HESSELBO}

Stephen Hesselbo is in the Department of Earth

Sciences, University of Oxford, South Parks Road, Oxford OX1 3AN, UK.

e-mail:stephess@earth.ox.ac.uk 